\title{
HUBUNGAN NONSUICIDAL SELF-INJURY (NSSI) DENGAN ACQUIRED CAPABILITY FOR SUICIDE: STUDI META-ANALISIS
}

\author{
Puti Andini Pradipta ${ }^{1}$, Monty P. Satiadarma ${ }^{2}$, Untung Subroto ${ }^{3}$ \\ ${ }^{1}$ Program Studi Magister Psikologi Profesi, Universitas Tarumanagara Jakarta \\ Email: puti.717182010@stu.untar.ac.id \\ ${ }^{2}$ Fakultas Psikologi, Universitas Tarumanagara Jakarta \\ Email:montys@fpsi.untar.ac.id \\ ${ }^{3}$ Fakultas Psikologi, Universitas Tarumanagara Jakarta \\ Email: untungs@fpsi.untar.ac.id
}

Masuk : 29-04-2021, revisi: 21-10-2021, diterima untuk diterbitkan : 29-10-2021

\begin{abstract}
Suicide was the third leading cause of death in adolescents in the world in 2016 with a mortality rate of about 136,000 cases. Reasons teenagers commit suicide include family financial problems, psychological distress, low self-esteem, lack of confidence, and depression. In addition, the difficulty of professional help and social support from the surrounding environment also opens up opportunities for adolescents to commit suicide. Suicidal behavior is often associated with nonsuicidal self-injury (NSSI). NSSI is an act of self-injury with no intention to commit suicide, but according to the Interpersonal Theory for Suicide by Joiner (2005), NSSI's actions are considered to be one of the factors increasing the ability to commit suicide attempts (acquired capability). This study is aimed at exploring the relationship between NSSI and acquired capability for suicide by meta-analysis study. Eight studies from 119 articles involving the term NSSI and acquired capability were studied using the random-effects model. A total of 3398 samples were included in the study. The results showed that the effect size between NSSI and acquired capability was ( $r=$ .208), which means that NSSI is positively correlated with acquired capability and has a weak relationship. The results of this study also show that this study has a high heterogeneity value $\left(I^{2}=91,48\right)$ and there is no publication bias.
\end{abstract}

Keywords: NSSI, acquired capability, suicide, adolesence, meta-analysis

\begin{abstract}
ABSTRAK
Bunuh diri adalah penyebab kematian nomor tiga pada remaja di dunia pada tahun 2016 dengan angka kematian sekitar 136.000 kasus. Alasan remaja melakukan bunuh diri antara lain adalah masalah-masalah keuangan keluarga, distres psikologis, rendahnya harga diri, kurang percaya diri, dan depresi. Selain itu, sulitnya pertolongan tenaga profesional dan dukungan sosial dari lingkungan sekitarnya juga membuka peluang para remaja untuk melakukan percobaan bunuh diri. Perilaku bunuh diri sering dihubungkan dengan Nonsuicidal Self-Injury (NSSI). NSSI merupakan tindakan perusakan diri dengan tanpa adanya keinginan untuk bunuh diri, namun menurut teori Interpersonal Theory for Suicide oleh Joiner (2005), tindakan NSSI dianggap menjadi salah satu faktor meningkatnya kemampuan seseorang untuk melakukan percobaan bunuh diri (acquired capability). Penelitian ini bertujuan untuk mengeksplorasi hubungan antara NSSI dan acquired capability dengan studi meta-analisis. Delapan artikel korelasional dari 119 artikel yang melibatkan istilah NSSI dan acquired capability dipelajari menggunakan randomeffect models. Sebanyak 3398 sampel dilibatkan dalam penelitian ini. Hasil penelitian menunjukkan nilai effect size antara NSSI dan acquired capability adalah sebesar $(\mathrm{r}=.208)$, yang berarti NSSI berkorelasi positif dengan acquired capability dan memiliki hubungan yang lemah. Hasil penelitian ini juga menunjukkan bahwa studi ini memiliki nilai heterogenitas yang tinggi $\left(I^{2}=91,48\right)$ dan tidak terdapat bias publikasi.
\end{abstract}

Kata Kunci: NSSI, acquired capability, Bunuh diri, Remaja, Meta-analisis

\section{PENDAHULUAN}

\section{Latar Belakang}

Bunuh diri adalah penyebab kematian nomor tiga pada remaja di dunia pada tahun 2016 dengan angka kematian sekitar 136.000 kasus. Penelitian yang dilakukan oleh Uddin et al. (2019) menemukan bahwa dari total sampel 229.129 remaja diperoleh prevalensi ide bunuh diri sebesar $16,9 \%$ (38.722), perencanaan bunuh diri 17,0\% (38.951), dan percobaan bunuh diri 17,0\% (38.951) dalam 12 bulan. Uddin et al. (2019) juga mengungkapkan bahwa masalah-masalah keuangan keluarga dan distres psikologis, di samping rendahnya harga diri, kurang percaya diri, 
dan depresi menjadi alasan remaja melakukan tindakan bunuh diri; di samping itu sulitnya pertolongan tenaga profesional dan dukungan sosial dari lingkungan sekitarnya membuka peluang para remaja untuk melakukan percobaan bunuh diri.

Perilaku bunuh diri sering dihubungkan dengan Nonsuicidal Self-Injury (NSSI). Menurut DSM V (APA, 2013) NSSI merujuk pada perusakan yang disengaja pada jaringan tubuh termasuk menggores, menusuk, membakar, membenturkan kepala yang bersifat mencederai individu tanpa adanya niat untuk bunuh diri dan untuk tujuan yang tidak disetujui secara sosial. Perilaku NSSI umumnya terjadi pada rentang usia remaja dan dewasa awal dengan populasi sekitar 15-20\%, perilaku ini biasanya muncul pada umur 13 atau 14 tahun (Klonsky et al., 2014). Sadeh et al. (2014) menyebutkan bahwa dalam sampel komunitas, 13-36\% remaja secara umum, dan 60-80\% dari pasien psikiatri remaja melakukan NSSI. Berbagai faktor menjadi alasan remaja sering melakukan NSSI, di antaranya untuk meregulasi emosi dan menghilangkan emosi negatif, menghukum dirinya sendiri, untuk mendapatkan perhatian dari lingkungannya, serta untuk mendapatkan perasaan kelegaan dari rasa sakit yang dialami.

Meskipun NSSI dan bunuh diri sama-sama merupakan bentuk perilaku yang menyakiti diri sendiri, perilaku ini telah dibedakan berdasarkan niat, frekuensi, dan tingkat kematiannya (Hamza et al., 2012). Klonsky et al. (2014) menjelaskan orang yang terlibat dalam NSSI tidak berniat untuk mengakhiri hidup mereka sendiri. Bahkan, NSSI paling sering dilakukan tanpa adanya ide bunuh diri. Hal ini menunjukkan kerancuan hubungan antara NSSI dengan perilaku bunuh diri. Berbagai penelitian mengungkapkan hubungan antara NSSI dan perilaku bunuh diri. Klonsky et al. (2014) menjelaskan bahwa NSSI menjadi salah satu prediktor kuat suicide attempt (SA), bahkan lebih kuat dibandingkan sejarah percobaan bunuh diri sebelumnya. Coppersmith et al. (2017) dalam penelitiannya menemukan bahwa $24,1 \%$ dari partisipan NSSI pernah melakukan percobaan bunuh diri. Sementara dalam penelitian Fox et al. (2018) ditemukan bahwa $76.62 \%$ partisipan NSSI dalam penelitiannya pernah memiliki ide bunuh diri selama satu bulan terakhir, dan $42.86 \%$ melakukan SA. Penelitian Whitlock et al. (2012) mendukung gagasan bahwa NSSI dapat berfungsi sebagai "pintu gerbang" untuk munculnya perilaku dan pikiran bunuh diri, serta perlunya respon dan intervensi NSSI di awal episode muncul. Meskipun demikian, NSSI jarang dikutip dalam penelitian bunuh diri sebagai faktor risiko perilaku dan pikiran bunuh diri pada remaja. Hal ini dikarenakan perilaku NSSI pada remaja sering dikenal sebagai perilaku mencari perhatian, sehingga sering diabaikan oleh lingkungan sekitarnya, terutama apabila tidak ditemani oleh penanda klinis (clinical symptoms) lainnya.

Salah satu teori yang telah diusulkan untuk menjelaskan hubungan antara NSSI dan upaya bunuh diri adalah oleh Joiner (2005) dalam Interpersonal Theory for Suicide. Menurut Joiner, untuk mencoba atau mati dengan bunuh diri, individu tidak hanya harus berkeinginan untuk mengakhiri hidup mereka dengan menunjukkan ide bunuh diri tetapi juga dapat mengatasi naluri mempertahankan diri dasar, yaitu mereka harus memperoleh kemampuan untuk bunuh diri atau disebut dengan acquired capability.

Kemampuan untuk bunuh diri dapat diperoleh individu ia tidak lagi memiliki ketakutan terhadap kematian dan telah memiliki toleransi rasa sakit yang tinggi. Menurut Interpersonal Theory for Suicide, seseorang yang dapat melakukan percobaan bunuh diri yang letal memiliki keinginan dan kemampuan tersebut. acquired capability (AC) adalah kemampuan yang diperoleh individu dari pengalaman hidup dan hasil belajar, bukan bersifat bawaan. Mengingat bahwa kematian secara inheren menakutkan dan secara fisik menyakitkan, memperoleh acquired capability membuat seseorang terbiasa dengan rasa sakit dan pengalaman yang mengancam jiwa. Ketika seseorang 
mengatasi rasa takut ini, dia mungkin bisa melukai diri sendiri. Kemampuan untuk mati diperoleh melalui serangkaian peristiwa menyakitkan dan provokatif yang mengurangi rasa takut akan kematian (fear of death) dan meningkatkan toleransi rasa sakit (pain tolerance). Salah satu dari peristiwa menyakitkan ini adalah NSSI (Joiner, 2005).

Joiner (2005) mengemukakan bahwa dengan keterlibatan NSSI yang berulang-ulang, proses rasa sakit dan takut akan cedera mungkin semakin diimbangi oleh proses pelepasan dari emosi negatif, yang seiring waktu akan mengarah pada sensitivitas nyeri yang lebih sedikit dan rasa takut akan kematian yang semakin berkurang. Hubungan antara NSSI dan sensitivitas nyeri yang lebih rendah dan rasa takut akan kematian didorong oleh desensitisasi atau habituasi, serta oleh motivasi untuk hukuman diri yang mengarah pada toleransi yang lebih besar terhadap rasa sakit (Hamza et al., 2014). Berbagai penelitian dilakukan untuk melihat hubungan antara NSSI dengan acquired capability. Penelitian cross-sectional oleh Franklin et al. (2011) menunjukkan bahwa individu yang terlibat dalam NSSI memiliki acquired capability yang dilaporkan lebih tinggi dibandingkan dengan non-NSSI. Selain itu terdapat penelitian oleh Willoughby, Heffer, dan Hamza (2015) yang menemukan mekanisme potensial untuk hubungan antara NSSI dan upaya bunuh diri dapat diperoleh dengan acquired capability, dan menunjukkan bahwa menargetkan keterlibatan NSSI dapat membantu mencegah individu dari memperoleh kemampuan untuk melakukan upaya cedera diri yang mematikan.

Mengingat perannya yang potensial dalam meningkatkan toleransi rasa sakit dan rasa takut terhadap kematian, NSSI dapat meningkatkan risiko bunuh diri melalui peningkatan acquired capability. Sehingga dibutuhkan asesmen lanjutan untuk mencari tahu apakah remaja yang sedang memiliki episode NSSI memiliki kemampuan untuk bunuh diri. Hubungan ini perlu diperjelas secara lebih luas dan terukur agar para praktisi dan lingkungan sosial pelaku NSSI dapat mengetahui pentingnya peranan variabel acquired capability pada remaja dengan NSSI, sehingga dapat mengantisipasi dan memberikan perhatian yang tepat untuk menekan angka bunuh diri pada remaja.

\section{Rumusan Masalah}

Berbagai penelitian telah dilakukan untuk mencari tahu hubungan NSSI dengan acquired capability for suicide, namun seringkali hasil penelitian sebelumnya menunjukkan hasil yang berbeda dan terdapat inkonsistensi antara hubungan NSSI dengan acquired capability for suicide, sehingga dalam hal ini peneliti merasa perlu dilakukan penelitian meta-analisis dengan tujuan mencari tahu hubungan NSSI dengan acquired capability for suicide pada remaja secara lebih luas untuk mendapatkan hasil penelitian yang general secara kuantitatif.

\section{METODE PENELITIAN}

Metode penelitian yang digunakan adalah meta-analisis dengan kriteria inklusi (a) publikasi dengan metode korelasional yang meneliti variabel NSSI dan acquired capability; (b) publikasi yang dipilih adalah publikasi yang memiliki rerata partisipan berusia 12-21 tahun; (c) publikasi yang dipilih tidak ditentukan tahun secara khusus; (d) menggunakan alat ukur apa pun untuk mengukur NSSI dan acquired capability, selama merupakan alat ukur yang telah memiliki validitas dan reliabilitas yang baik; (e) pada penelitian yang dimasukkan juga harus mengukur kedua aspek dari NSSI (frekuensi dan metode) dan kedua aspek dari acquired capability (fearlessness about death and pain tolerance). Kriteria eksklusi (a) hanya mengukur salah satu aspek dari variabel-variabel tersebut, (b) penelitian tidak menyajikan temuan empiris (laporan kasus, ulasan, atau rekomendasi praktik), (c) variabel tidak diukur menggunakan kuesioner, melainkan menggunakan suatu perilaku tertentu. Studi ini mengikuti pedoman Item Pelaporan 
Pilihan untuk Tinjauan Sistematik dan Meta-Analisis (PRISMA) (Liberati et al., 2009). Pencarian melalui database online PsycINFO, Google Scholar, dan PubMed hingga 28 Mei 2020. Pencarian dilakukan dengan menggunakan istilah yang terkait dengan NSSI ("NSSI, "Deliberately self harm", "self injury"), dan acquired capability. Analisis data menggunakan Program Comprehensive Meta-Analysis software (CMA 3.0) digunakan untuk menganalisa effect size, bias publikasi, dan heterogenitas artikel. Penilaian kualitas penelitian dalam penelitian ini diadaptasi dari Penilaian Kualitas dan Alat Validitas untuk Studi Korelasi (Cicolini et al., 2013).

\section{Gambar 1}

Diagram Alur PRISMA

PRISMA 2009 Flow Diagram
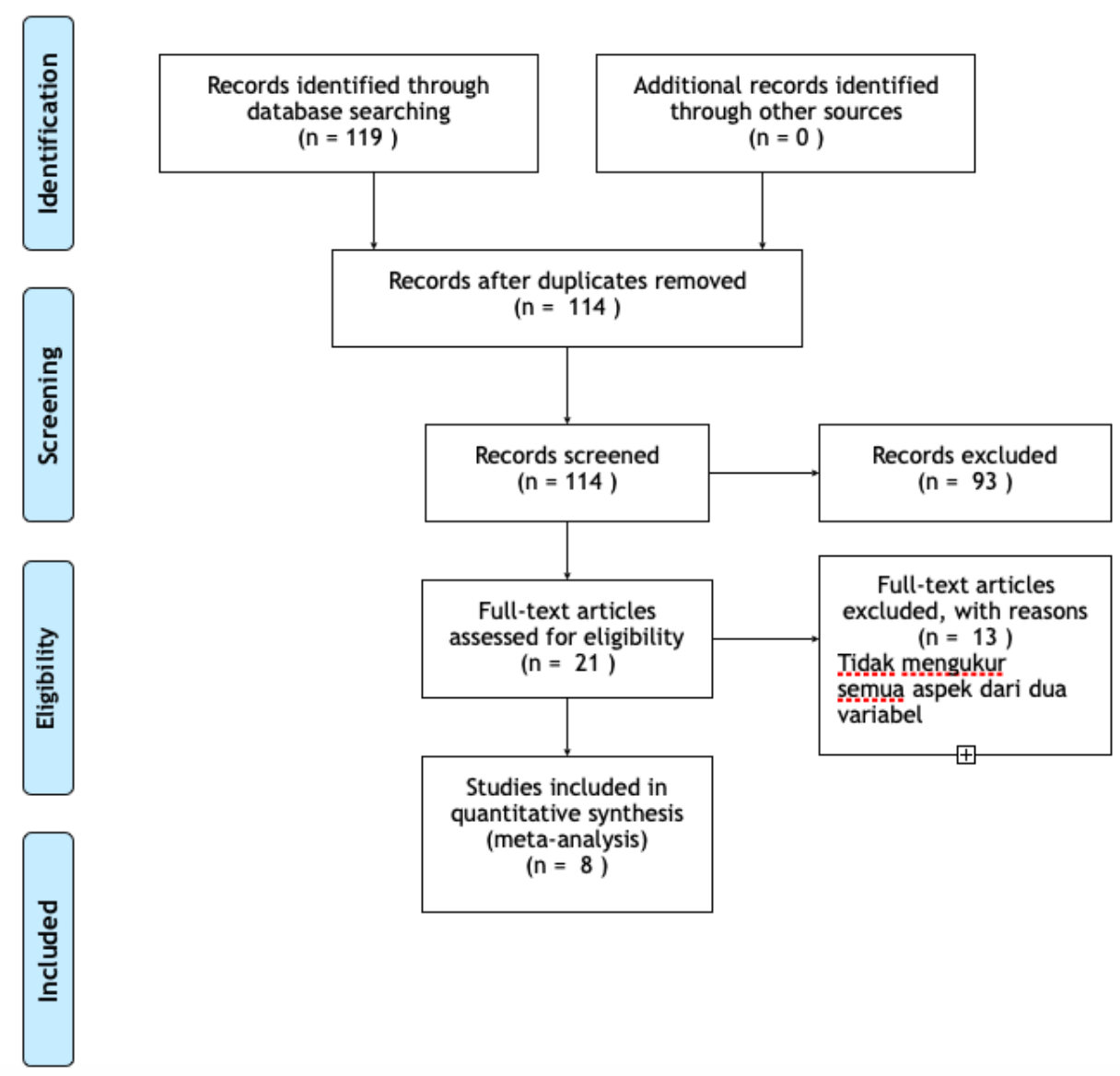

Studies included in

quantitative synthesis (meta-analysis) $(n=8)$

\section{HASIL DAN PEMBAHASAN}

\section{Karakteristik Studi}

Dalam penelitian ini terdapat delapan studi korelasional yang dianalisis, yang diambil dari tahun 2011-2020. Total sampel penelitian sebesar 3398 dengan rerata umur 19.8 tahun yang merupakan umur pada remaja akhir.

Tabel 1

Gambaran Karakteristik Partisipan

\begin{tabular}{clllll}
\hline No. & Studi & Tahun & Usia & Alat ukur NSSI \& AC & N \\
\hline 1 & Franklin, Hessel, \& Prinstein & 2011 & 19.25 & FASM, ACSS-20 & 137 \\
2 & Holaday & 2013 & 20 & SHBQ, ACSS-20 & 1132
\end{tabular}




\begin{tabular}{clllll}
3 & Meuhlenkamp, et al & 2015 & 19.86 & ISAS, ACSS-20 & 520 \\
4 & Willoughby, Heffer, \& Hamza & 2015 & 19.11 & ISAS, ACSS-5 & 502 \\
5 & wolford-Clevenger, et al & 2015 & 18.8 & PDQ4, ACSS-20 & 611 \\
6 & George, et al & 2016 & 20.9 & SITBI, ACWRSS & 237 \\
7 & Burke, et al & 2018 & 20.6 & FAFSI, ACSS-20 & 192 \\
8 & La Guardia, et al & 2020 & 20 & DHSI-S, ACSS-20 & 67 \\
\hline & Total & & & 3398
\end{tabular}

Note. FASM: Functional Assessment of Self-Mutilation, ACSS: Acquired Capablity for Suicide Scale, SHBQ: Self-Harm Behavior Questionnaire, ISAS: Inventory of Statements about Self-Injury, PDQ4: Personality Diagnostiq Questionnaire, SITBI: Self-Injurious Thoughts and Behaviors Questionnaire, FAFSI: The Form and Function of Self-Injury, DHSI-S: Deliberate Self-Harm Inventory-Short Version, ACWRSS: Acquired Capability with Rehearsal for Suicide Scale

\section{Distribusi Data Penelitian}

Tabel berikut menunjukkan distribusi data penelitian yang diteliti, ditambah dengan informasi tentang koefisien korelasi yang telah diubah menjadi Fisher's Z, standard error, varians, nilai Z, dan p-value.

\section{Tabel 2}

Distribusi Data Penelitian

\begin{tabular}{|c|c|c|c|c|c|c|c|c|}
\hline Sitasi & Korelasi & Umur (SD) & Tipe Sampel & Fisher's Z & Std err & Varian & Z-value & P-value \\
\hline $\begin{array}{l}\text { Franklin, Hessel, \& } \\
\text { Prinstein (2011) }\end{array}$ & .300 & 19.25 & Univ & .310 & 0,125 & 0,016 & 2,476 & .013 \\
\hline Holaday (2013) & .070 & $20(7.42)$ & Univ & -.070 & 0,065 & 0,004 & $-1,073$ & .283 \\
\hline $\begin{array}{l}\text { Meuhlenkamp et al. } \\
\text { (2015) }\end{array}$ & .370 & $19.86(1.65)$ & Univ & .388 & 0,086 & 0,007 & 4,496 & .000 \\
\hline $\begin{array}{l}\text { Willoughby, Heffer, } \\
\text { \& Hamza (2015) }\end{array}$ & .112 & $19.11(1.05)$ & Univ & .112 & 0,030 & 0,001 & 3,779 & .000 \\
\hline $\begin{array}{l}\text { Wolford-Clevenger, } \\
\text { et al (2015) }\end{array}$ & .160 & $18.8(1.93)$ & Univ & .161 & 0,045 & 0,002 & 3,605 & .000 \\
\hline George, et al (2016) & .440 & $20.9(4.93)$ & Univ & .472 & 0,041 & 0,002 & 11,644 & .000 \\
\hline Burke, et al (2018) & .100 & $20.6(2.64)$ & Univ & .100 & 0,044 & 0,002 & 2,281 & .023 \\
\hline $\begin{array}{l}\text { La Guardia, et al } \\
(2020)\end{array}$ & .230 & $20(3.34)$ & Univ & .234 & 0,073 & 0,005 & 3,220 & .001 \\
\hline Random Effect Size & & & & 0.208 & 0.063 & 0.004 & 3.281 & 0.001 \\
\hline
\end{tabular}

\section{Effect Size}




\section{Gambar 2}

Statistik Karakteristik Studi

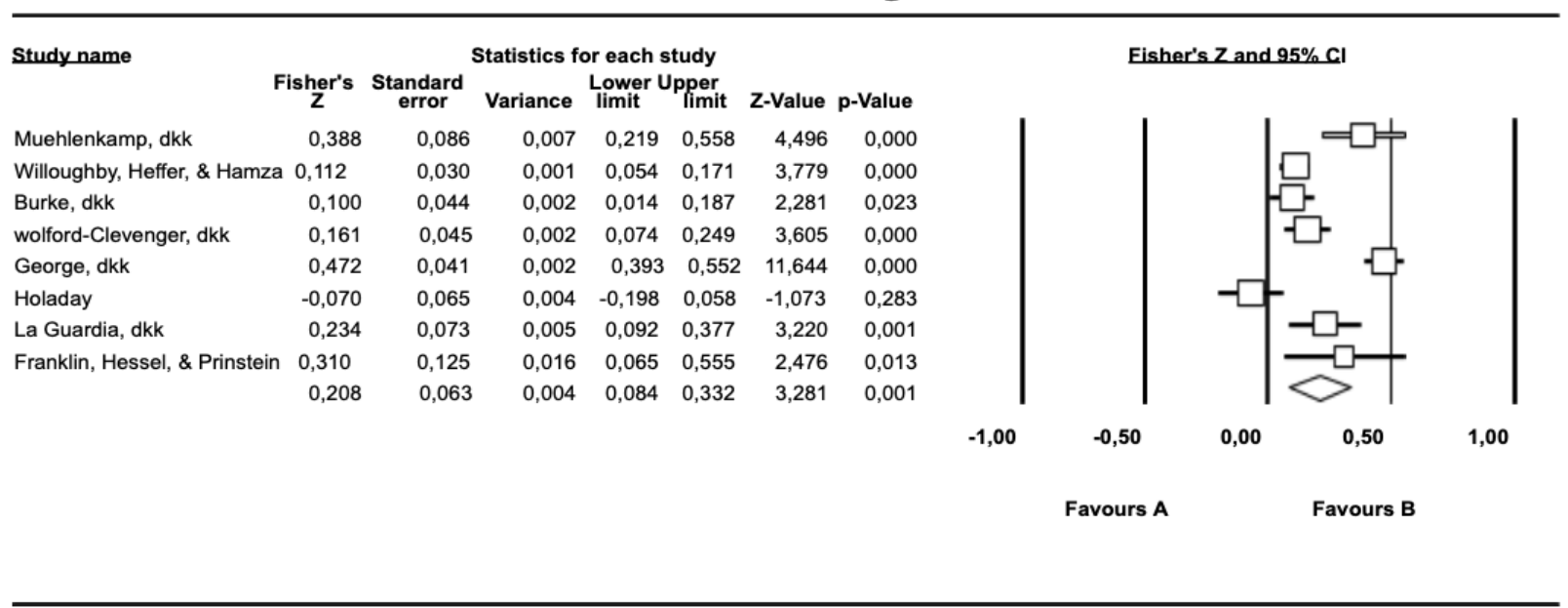

\section{Meta Analysis}

Gambar di atas menjelaskan bahwa hasil dari meta-analisis dengan 91,48\% Convidence Interval (CI). Garis plot menunjukkan CI yang lebih luas menunjukkan bahwa penelitian memiliki presisi rendah, dengan estimasi paling akurat adalah penelitian George, et al (2016). Secara keseluruhan kesimpulan informasi pada $95 \%$ confidence interval menunjukkan bahwa pada studi di atas terdapat korelasi antara NSSI dengan acquired capability.

\section{Gambar 3}

Analisis Effect Size

Model

Model

Fixed

Random effects
Number

Studies
Effect size and $95 \%$ confidence interval

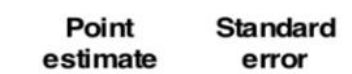

Variance Lower limit Upper limit

$\begin{array}{llll}0,017 & 0,000 & 0,158 & 0,225\end{array}$

$\begin{array}{llll}0,063 & 0,004 & 0,084 & 0,332\end{array}$

Analisis nilai effect size yang digunakan pada penelitian ini adalah dengan random-effect model yang dikarenakan karakteristik populasi yang non-homogen. Dari gambar diatas didapatkan hasil random-effect size sebesar 0.208 (efek lemah), dengan Z-value $=3.281$ dan $\mathrm{p}=0.001$. Berdasarkan effect size value dengan $\mathrm{p}<.01$, hipotesis penelitian ini tidak ditolak, sehingga dapat diartikan terdapat hubungan positif yang lemah antara NSSI dan acquired capability.

\section{Studi Heterogenitas}

Statistik $\mathrm{I}^{2}$ untuk heterogenitas adalah $91.480 \%(91.48 \% \%), \mathrm{p}=<0,000$, menunjukkan heterogenitas yang signifikan dalam studi yang diambil. $\mathrm{I}^{2}$ menunjukkan jumlah variabilitas yang tidak dapat dijelaskan secara kebetulan. Dengan kata lain, indeks $\mathrm{I}^{2}$ menjelaskan persentase estimasi variabilitas $(91.48 \%$ \%) dalam hasil di seluruh studi yang disebabkan oleh perbedaan nyata dan bukan karena kebetulan. Selain itu, Random effect size digunakan untuk mengukur effect size dikarenakan heterogenitas penelitian yang tinggi. 


\section{Gambar 4}

Uji Heterogenitas

Heterogene

I-squared

91,480
Taursquared

Standard
Error

$0,019 \quad 0,000 \quad 0,167$

\section{Uji Bias Publikasi}

Bias publikasi diuji dengan menggunakan Funnel Plots, Egger's Regression Intercept, dan Duval and Tweedie's trim and fill. Pada ketiga uji tersebut, tidak ditemukan adanya bias publikasi.

\section{Gambar 5}

Funnel Plot

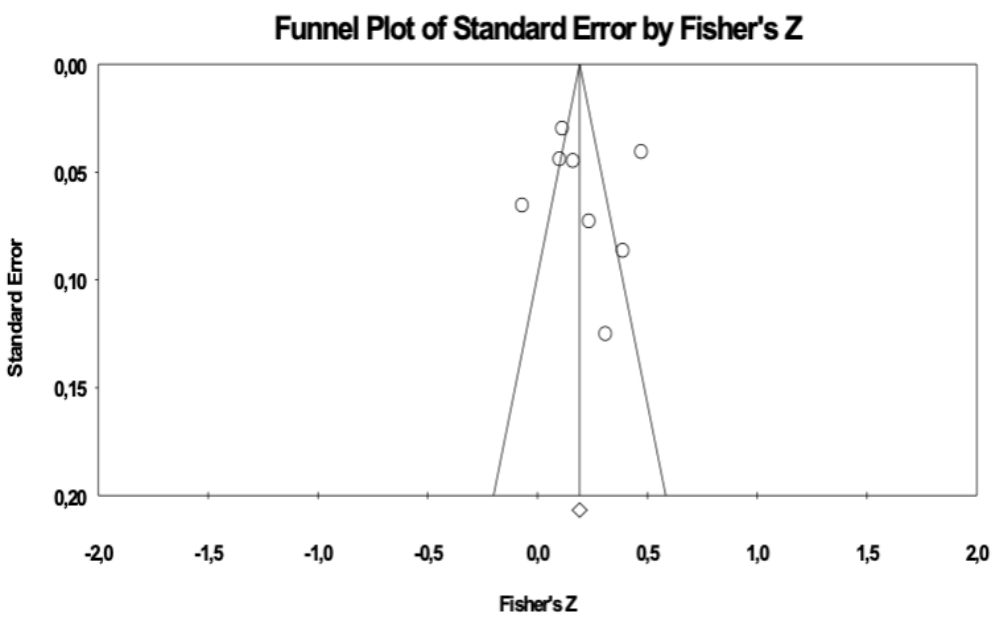

\section{Gambar 6}

Egger's Regression Intercept

Egger's regression intercept

$\begin{array}{lr}\text { Intercept } & 1,14633 \\ \text { Standard error } & 3,40923 \\ \text { 95\% lower limit (2-tailed) } & -7,19576 \\ \text { 95\% upper limit (2-tailed) } & 9,48841 \\ \text { t-value } & 0,33624 \\ \text { df } & 6,00000 \\ \text { P-value (1-tailed) } & 0,37407 \\ \text { P-value (2-tailed) } & 0,74814\end{array}$




\section{Gambar 7 \\ Duval and Tweedie's Trim and Fill \\ Duval and Tweedie's trim and fill}

\begin{tabular}{lccccc} 
& \multicolumn{3}{c}{ Fixed Effects } & \multicolumn{3}{c}{ Random Effects } \\
$\begin{array}{l}\text { Studies } \\
\text { Trimmed }\end{array}$ & $\begin{array}{c}\text { Point } \\
\text { Estimate }\end{array}$ & $\begin{array}{l}\text { Lower } \\
\text { Limit }\end{array}$ & $\begin{array}{l}\text { Upper } \\
\text { Limit }\end{array}$ & $\begin{array}{c}\text { Point } \\
\text { Estimate }\end{array}$ & $\begin{array}{c}\text { Lower } \\
\text { Limit }\end{array}$ \\
& & & & & \\
& 0,19153 & 0,15778 & 0,22527 & 0,20814 & 0,08381 \\
& 0,19153 & 0,15778 & 0,22527 & 0,20814 & 0,08381
\end{tabular}

Pada penelitian meta-analisis ini, didapatkan nilai effect size hubungan NSSI dengan acquired capability sebesar .208, atau dapat diartikan dengan korelasi lemah. Nilai effect size sebesar .208 diartikan sebagai NSSI berkorelasi dengan acquired capability sebesar $20 \%$. Hasil korelasi $20 \%$ didapatkan dari aspek-aspek yang dimiliki oleh NSSI yaitu variasi metode NSSI yang digunakan, dan frekuensi NSSI dilakukan dengan korelasinya terhadap aspek-aspek dari acquired capability yaitu fear of death dan pain tolerance. Peneliti menyimpulkan beberapa faktor yang dapat menjelaskan mengapa hubungan yang lemah ini didapatkan. Joiner (2005) menjelaskan terdapat faktor kerentanan secara biologis yang berhubungan dengan acquired capability. Pada penelitian meta-analisis ini, artikel-artikel yang dianalisis memiliki partisipan non-klinis, yang tidak merepresentasikan populasi yang parah. Hasil ini sejalan dengan penelitian yang dilakukan oleh Klonsky dan Olino (2008) dan penelitian Ammerman et al. (2016) dengan sampel non-klinis dewasa muda, dengan hasil penelitian yang menunjukkan bahwa pengalaman nyeri selama NSSI mungkin memainkan peran yang berbeda bagi mereka yang terlibat dalam NSSI di tingkat klinis. Faktor berikutnya adalah level dari painful and provocative events (PPE) yang memengaruhi tingkat keparahan dari perilaku NSSI dan acquired capability. Pengalaman hidup yang tidak langsung, jarang terjadi, atau umumnya tidak parah mungkin tidak menanamkan acquired capability yang serius dan mematikan. Selain itu, seluruh artikel yang digunakan dalam penelitian ini memiliki mean persentase partisipan perempuan sebesar $72.4 \%$. Sebuah basis literatur besar telah mendokumentasikan bahwa ada perbedaan gender dalam pain tolerance (Fillingim et al., 2009) dan fear of death, dengan laki-laki menunjukkan toleransi nyeri yang lebih tinggi dan lebih rendah fear of death dibandingkan perempuan, sementara Joiner (2005) juga menjelaskan bahwa secara tradisional, pria disosialisasikan untuk lebih tidak mengekspresikan rasa takut dibandingkan dengan wanita. Kemungkinan faktor yang terakhir adalah alat ukur yang digunakan untuk mengukur NSSI dan acquired capability for suicide scale (ACSS). Ribeiro et al. (2014) dalam penelitiannya menunjukkan sejumlah faktor yang menggarisbawahi pentingnya untuk mengevaluasi kembali dan berpotensi mengembangkan kembali alat ukur ACSS-20

\section{KESIMPULAN DAN SARAN}

Berdasarkan studi meta-analisis yang dilakukan pada delapan artikel yang mengukur NSSI dan acquired capability, didapatkan hasil terdapat hubungan yang lemah antara NSSI dengan acquired capability, nilai random effect size yang didapatkan adalah sebesar .208. Hasil ini menunjukkan bahwa NSSI memiliki pengaruh terhadap acquired capability sebesar 20\%. Penelitian metaanalisis ini bebas dari bias publikasi, dan juga memiliki heterogenitas yang tinggi, hal ini disebabkan oleh variansi hasil penelitian pada artikel yang di inklusikan cukup beragam. Terdapat berbagai faktor yang menjelaskan mengapa hasil penelitian yang didapatkan kurang sesuai dengan teori Joiner (2005), yaitu di antaranya adalah populasi dari artikel-artikel yang digunakan adalah non-klinis sehingga memengaruhi tingkat keparahan kondisi partisipan serta lingkungan sekitar partisipan, aspek PPE (painful and provocative events) yang memengaruhi tingkat keparahan NSSI 
dan pengaruhnya terhadap level acquired capability, mayoritas gender partisipan pada artikel adalah perempuan yang pada teori Joiner memiliki tingkat fear of death dan pain tolerance yang lebih rendah dibandingkan dengan pria, alat ukur NSSI dan acquired capability yang berbedabeda, serta keterbatasan artikel yang hanya memasukkan delapan artikel.

Peneliti memberikan beberapa saran yang dapat digunakan untuk penelitian selanjutnya mengenai hubungan antara NSSI dengan acquired capability. Pertama, disarankan untuk melakukan penelitian yang lebih spesifik pada aspek-aspek dari NSSI, seperti mengkhususkan aspek frekuensi atau metode yang digunakan, serta aspek dari acquired capability yaitu fearlessness of death atau pain tolerance, sehingga hasil penelitian dalam menjelaskan aspek manakah yang lebih signifikan memengaruhi variabel tersebut dan hubungannya dengan dengan variabel lain. Kemudian, peneliti selanjutnya diharapkan menggunakan alat ukur yang sama untuk mengukur NSSI dan acquired capability, dengan begitu hasil yang didapatkan akan lebih homogen. Penelitian selanjutnya diharapkan juga dapat melakukan studi dengan menggunakan artikel yang lebih banyak dan homogen. Selain itu, disarankan juga untuk mencoba untuk melakukan penelitian dengan membandingkan hasil penelitian antara partisipan pria dan perempuan, serta melakukan penelitian yang mengkhususkan pada satu gangguan klinis tertentu penyebab NSSI.

\section{REFERENSI}

American Psychiatric Association. (2013). Diagnostic and statistic manual of mental disorder $5^{\text {th }}$ edition. American Psychiatric Association.

Ammerman, B. A., Burke, T. A., Alloy, L. B., \& McCloskey, M. S. (2016). Subjective pain during NSSI as an active agent in suicide risk. Psychiatry Research, 236, 80-85. https://doi.org/10.1016/j.psychres.2015.12.028

Burke, T. A., Ammerman, B. A., Knorr, A. C., Alloy, L. B., \& McCloskey, M. S. (2018). Measuring acquired capability for suicide within an ideation-to-action framework. Psychology of Violence, 8(2), 277-286. https://doi.org/10.1037/vio0000090

Cicolini, G., Comparcini, D., \& Simonetti, V. (2013). Workplace empowerment and nurses' job satisfaction: a systematic literature review. Journal of Nursing Management, 22(7), 855871. https://doi.org/10.1111/jonm.12028

Coppersmith, D. D. L., Nada-Raja, S., \& Beautrais, A. L. (2017). Non-suicidal self-injury and suicide attempts in a New Zealand birth cohort. Journal of Affective Disorders, 221, 89-96.

Fillingim, R. B., King, C. D., Ribeiro-Dasilva, M. C., Rahim-Williams, B., \& Riley, J. L. (2009). Sex, gender, and pain: A review of recent clinical and experimental findings. The Journal of Pain, 10(5), 447-485. https://doi.org/10.1016/j.jpain.2008.12.001

Fox, K., Franklin, J., Ribeiro, J., Kleiman, E., Bentley, K., Nock, M. (2015). Meta-analysis of risk factors for nonsuicidal self-injury. Clinical Psychology Review, 42. htpps://doi.org/10.1016/j.cpr.2015.09.002

Franklin, J. C., Hessel, E. T., \& Prinstein, M. J. (2011). Clarifying the role of pain tolerance in suicidal capability. Psychiatry Research, 189(3), 362-367. https://doi.org/10.1016/j.psychres.2011.08.001

George, S. E., Page, A. C., Hooke, G. R., \& Stritzke, W. G. (2016). Multifacet assessment of capability for suicide: Development and prospective validation of the Acquired Capability With Rehearsal for Suicide Scale. Psychological assessment, 28(11), 1452-1464. https://doi.org/10.1037/pas0000276

Hamza, C. A., Willoughby, T., \& Armiento, J. (2014). A laboratory examination of pain threshold and tolerance among nonsuicidal self-injurers with and without self-punishing motivations. Archives of Scientific Psychology, 2(1), 33-42. https://doi.org/10.1037/arc0000008 
Hamza, C. A., Stewart, S. L., \& Willoughby, T. (2012). Examining the link between nonsuicidal self-injury and suicidal behavior: A review of the literature and an integrated model. Clinical Psychology Review, 32(6), 482-495. https://doi.org/10.1016/j.cpr.2012.05.003

Holaday, T. C. (2013). Suicide-related imagining and acquired capability: investigating the role of imagery in self-harm behaviors. Western Kentucky University.

Joiner, T. (2005). Why people die by suicide. Harvard University Press.

Klonsky, E. D., \& Olino, T. M. (2008). Identifying clinically distinct subgroups of self-injurers among young adults: A latent class analysis. Journal of Consulting and Clinical Psychology, 76(1), 22-27. https://doi.org/10.1037/0022-006X.76.1.22

Klonsky, E. D., Victor, S., \& Saffer, B. (2014). Nonsuicidal self-injury: What we know, and what we need to know. Canadian journal of psychiatry, 59. 565-568. https://doi.org/10.1177/070674371405901101

La Guardia, A. C., Cramer, R. J., Bryson, C. N., \& Emelianchik-Key, K. (2020). Analysis of personality, suicide, and self-injury in emerging adulthood. Journal of College Counseling, 23(1), 57-70. https://doi/org/10.1002/jocc.12149.

Liberati, A., Altman, D. G., Tetzlaff, J., Mulrow, C., Gøtzsche, P. C., Ioannidis, J. P. A., ... Moher, D. (2009). The PRISMA statement for reporting systematic reviews and meta-analyses of studies that evaluate health care interventions: explanation and elaboration. Journal of Clinical Epidemiology, 62(10), e1-e34. https://doi.org/10.1016/j.jclinepi.2009.06.006

Muehlenkamp, J. J., Hilt, L. M., Ehlinger, P. P., \& McMillan, T. (2015). Nonsuicidal self-injury in sexual minority college students: a test of theoretical integration. Child and Adolescent Psychiatry and Mental Health, 9(1). https://doi.org/10.1186/s13034-015-0050-y

Ribeiro, J. D., Witte, T. K., Van Orden, K. A., Selby, E. A., Gordon, K. H., Bender, T. W., \& Joiner, T. E. (2014). Fearlessness about death: The psychometric properties and construct validity of the revision to the acquired capability for suicide scale. Psychological Assessment, 26(1), 115-126. https://doi.org/10.1037/a0034858

Sadeh, N., Londahl-Shaller, E. A., Piatigorsky, A., Fordwood, S., Stuart, B. K., McNiel, D. E., Klonsky, E. D., Ozer, E. M., Yaeger, A. M. (2014). Functions of non-suicidal self-injury in adolescents and young adults with borderline personality disorder symptoms. Psychiatry Res, 216, 217-222. https://doi.org/10.1016/j.psychres.2014.02.018

Uddin, R., Burton, N. W., Maple, M., Khan, S. R., \& Khan, A. (2019). Suicidal ideation, suicide planning, and suicide attempts among adolescents in 59 low-income and middle-income countries: a population-based study. The Lancet Child \& Adolescent Health, 3(4), 223-233. https://doi.org/10.1016/s2352-4642(18)30403-6

Whitlock, J., Muehlenkamp, J., Eckenrode, J., Purington, A., Baral Abrams, G., Barreira, P., \& Kress, V. (2013). Nonsuicidal self-injury as a gateway to suicide in young adults. Journal of Adolescent Health, 52(4), 486-492. https://doi.org/10.1016/j.jadohealth.2012.09.010

Willoughby, T., Heffer, T., \& Hamza, C. A. (2015). The link between nonsuicidal self-injury and acquired capability for suicide: A longitudinal study. Journal of Abnormal Psychology, 124(4), 1110-1115. htpps://doi.org/10.1037/abn0000104

Wolford-Clevenger, C., Febres, J., Zapor, H., Elmquist, J., Bliton, C., \& Stuart, G. L. (2014). Interpersonal violence, alcohol use, and acquired capability for suicide. Death Studies, 39(4), 234-241. https://doi.org/10.1080/07481187.2014.985405 